\title{
Review
}

\section{War and the politics of ethics}

\author{
Maja Zehfuss
}

Oxford, OUP, 2018, xiv+231pp., ISBN: 978-0-19-880799-5

Contemporary Political Theory (2020) 19, S271-S274. https://doi.org/10.1057/s41296019-00348-6; published online 9 September 2019

War and the Politics of Ethics investigates 'post-Cold War Western war' as 'ethical war' (p. 9). According to Maja Zehfuss, a 'commitment to and invocation of ethics' serves to enhance 'the violence of war' (p. 9). She thinks 'ethics can serve this (political) purpose because it is (impossibly) construed as distinct from politics' (p. 9). Ethics 'enables and enhances war while obscuring that this is the case' (p. 12). It is 'seductive' (p. 14) and plays a role 'in the West's inability to recognize' its own use of force as violent. This allows 'the powerful and dangerous illusion that ethics can tame politics (and by implication war)' (p. 14). Ultimately, Zehfuss argues that 'the practice of ethical war undermines itself' (p. 28); that 'the humanitarian or ethical framing has produced the conditions of possibility for Western war and continues to do so'; and that '[e]thical war ... reinforces itself by shaping an imaginary within which the practice is supported and sustained' (p. 35).

Drawing on Derrida, Zehfuss goes on to diagnose an 'aporia': 'a situation where there is no right way forward, where the way forward is blocked', and where the 'West may wish to protect people from oppression and extermination, but in attempting to do so ... will itself oppress and kill' (p. 41). We cannot do right whatever we do, for ' $[\mathrm{w}] \mathrm{e}$ must make a decision, and this decision will not be authorized by or explicable within the rules of ethics' (p. 47). Zehfuss considers this a 'genuine dilemma: It is not that we have failed to find a smooth resolution but that there is none, given the structure of the ethico-political challenge' (p. 47). We have to take responsibility, but ethical rules will not settle how to do so: 'The issue is, in Derrida's terms, undecidable, made necessary by contradictory imperatives that cannot be answered' (p. 50). What is required is " an act of faith"' (p. 48).

This is how Zehfuss frames her argument in Chapter 1 ('Introduction') and Chapter 2 ('The Paradox of Ethical War and the Politics of Ethics'). She proceeds, in Chapters 3-5, to 'take the discourse - or rather text - of ethical war as an empirical problem to be investigated', examining 'how the text of ethical war works and fails to work - indeed undermines itself - so as to elucidate its effects' (p. 55). Revealing 'the liberal conceit that our ever-enhancing violence is in some way better than "theirs", (p. 178), Zehfuss analyses three practices of allegedly

(c) 2019 Springer Nature Limited. 1470-8914 Contemporary Political Theory Vol. 19, S4, S271-S274 
ethical war: (i) precision bombing (to minimize "collateral damage"), (ii) acquiring cultural knowledge (to win people's hearts and minds), and (iii) educating soldiers ethically (to produce good soldiers).

In chapter 6, on 'The Politics of War and the Limits of Ethics', Zehfuss concludes that 'despite designing and promoting ever better strategies for constraining the violence of war, the commitment to ethics has produced ever more overwhelming, intrusive, and deadly violence' (p. 187). She offers an excellent analysis of (revisionist) just war theorists' failure to recognize that 'the scholarly debate about what constitutes "true" principles of ethics is already shaped by politics without this being visible' (p. 192). According to Zehfuss, 'analytic philosophers' enthusiasm for hypothetical examples thought to sharpen conceptual thinking enables a philosophically authorized obliviousness to the politics that goes into the creation of the categories in the first place' (p. 194): 'The problem is that ethics is cordoned off against the real world, against politics'; indeed 'it is produced as desirable and true precisely on the basis of its exclusion from anything that might endanger its purity' (p. 195). One should hope for contemporary just war thinkers to engage with Zehfuss' critique and discontinue their intellectual practices.

Despite offering valuable insights, however, the book remains haunted by the just war framework it subjects to critique. In particular, two important limitations arise as a result of Zehfuss' tacit acceptance of the way in which just war thinking frames the problem of the sort of war that 'is to benefit the people of the countries it is waged against' (p. 16).

The first limitation is Zehfuss' narrow framing of the violence of war. She writes lucidly about the failure of those who praise precision bombing to account for allegedly accidental killing (pp. 73-81). And she is aware that '[c]ollateral damage assessments take into account only immediate damage at the point of impact' ( $\mathrm{p}$. 72). But she nonetheless follows the contemporary just war lead in reducing the violence of war to killing. While Zehfuss admits that 'killing is not the only problem with war', she reasons that it 'intuitively concerns many people the most' (p. 15). This raises the question of whether she does enough to counter just war thinking's colonizing influence on moral discourse about war (p. 24). Purportedly ethical war kills, but it also maims, traumatizes, rapes, tortures, displaces and starves. It subjects people to terrorizing regimes of surveillance (e.g. drone warfare). Why all these disastrous effects of war should be of lesser concern remains unclear. It also remains unclear why the violence of self-proclaimed ethical warriors should be investigated in isolation from their simultaneous atrocityinducing practices of non-military intervention, such as land grabbing, exporting weapons, stoking ethnic tension and the production of underdevelopment.

The second limitation is Zehfuss' acceptance of the dilemma of Western ethical war as genuine and inescapable. She does recognize the importance of raising questions 'about how we have arrived at the moment of making a decision about 
bombing targets, about what the killing is to achieve, and about what we might do other than bomb', and acknowledges that excluding these questions leaves us 'to make a disembodied calculation' (p. 90). She also suggests that 'the West is implicated' (p. 180) in the production of the problems that are seen to require ethical war as a response. Indeed, she laments 'that critiques of the politics of contemporary Western war have not penetrated the arguments about the ethics of war' (p. 55). And yet, while clarifying that she does 'not suggest that Western war is good or other-regarding' (p. 11), she also seems to assume that the pro-war horn of the dilemma is ordinarily genuine and adequately described as an 'inescapable ... aporia' (p. 195). The trouble here is not that Zehfuss cannot '[provide] a way of resolving the problem' (p. 195), but that she axiomatically accepts ethical war dilemmas as given, leaving 'us' in a deplorable position to decide 'when we should intervene, and when we should not' (p. 21). In particular, Zehfuss follows the way in which other-defending war is framed in contemporary just war thinking by insufficiently exploring the implications of Western powers already intervening in non-military ways that majorly contribute to reproducing conditions that purportedly demand war to prevent or stop killing.

The reader's worries are heightened in the final chapter, which introduces the story of Joshua Key, a US soldier who decided, while on leave in the United States, that he could not return to fight in Iraq. Zehfuss argues that Key 'confronts an aporia' (p. 202). But it is unclear on what basis Key's 'commitment to the military and his comrades' (p. 202) should be sufficient a consideration to justify looking at his decision as an aporia. What, exactly, is the dilemma here? What are the ethical rules that demand participation in a war that might have been branded as Operation Iraqi Freedom, but was clearly a moral crime? It does not help to add to the dilemma equation that Key will be prosecuted if he stays home, that his decision to desert 'is not acceptable to the vast majority of his family and friends', and that 'he faces an uncertain future with no income' (p. 202). If these considerations mattered in the way Zehfuss intends them to matter - that is, to support the claim that ' $[\mathrm{t}]$ here is no right way forward for Key that could be plotted out by theory' (p. 203 ) - it would seem to follow that every war and act of warfare presents all sorts of individuals with all sorts of irresolvable dilemmas. But if that were the case, the only conclusion to draw would be that wars sometimes happen and that there is nothing more we can say. In the end, everything remains as it is.

So there is a sense in which the book does meticulous work to arrive at a conclusion that is important but expected-that Western ethical war practices undermine themselves-while challenging neither the assumption that these dilemmas are genuine and inescapable nor the binaristic framing according to which the only two courses of action available when caught in such dilemmas are to drop bombs or not. Zehfuss simply appears to accept the view that one cannot protect humans without also attacking them (p. 48). In so doing she falls, however

(C) 2019 Springer Nature Limited. 1470-8914 Contemporary Political Theory Vol. 19, S4, S271-S274 S273 
inadvertently, into the just war trap of looking at human protection through the prism of war.

Publisher's Note Springer Nature remains neutral with regard to jurisdictional claims in published maps and institutional affiliations.

Michael Neu

University of Brighton, Brighton BN2 1RA, UK

m.neu@brighton.ac.uk 